\section{RELEVANSI MUATAN HISTORIS DAN NILAI \\ PENDIDIKAN KARAKTER DALAM NOVEL SEJARAH \\ RORO MENDUT VERSI Y. B. MANGUNWIYA DI ERA DIGITAL}

\author{
Febri Kevin Aditya*, Ismail Lutfi, Lutfiah Ayundasari \\ febri.kevin.aditya@um.ac.id \\ Universitas Negeri Malang, Indonesia.
}

\begin{abstract}
:
The digital age is inevitabile. The rapid influence of the digitization process has led to a deterioration of character values in students. Students' characters can be built through historical learning based
\end{abstract}

\section{尺.JPSI}

ARTICLE INFO:

Research Article

Article history:

Received o6 April 2021

Revised o7 May 2021

Accepted 10 May 2021

Published 16 June 2021

Available online 16 June 2021

(C)2021. Febri Kevin Aditya,

Ismail Lutfi, Lutfiah

Ayundasari. All rights reserved. on the search for meaning in the text of historical novels by exploring the educational value of the characters in them. This research aims to describe the value of character education in Roro Mendut historical novel version Y.B. Mangunwijaya and its relevance as reflective material to overcome various challenges of the digital age. This research is qualitative with Ferdinand de Saussure semiological analysis as an analytical technique. The results of this study showed the existence of historical content and found five main educational character values set by the Ministry of Education and Culture. The historical content and educational characters values found to have relevance to the modern life of the digital age. Relevance can be pursued as a historical learning material that builds the character of students. To be utilized in history learning in the classroom, special learning methods are required.

Keywords: Historical Content, Character Education Values, Historical Novels, Digital Age

\title{
PENDAHULUAN
}

Pandemi Covid-19 semakin menyadarkan bahwa digitalisasi adalah sebuah keniscayaan (Dwivedi dkk., 2020; Garad, Al-Ansi, \& Qamari, 2021). Mulai dari pertemuan tingkat tinggi kepala pemerintahan, seminar ilmiah dan sekolah, layanan peribadatan, hingga berbelanja dilakukan secara digital. Era digital membawa manfaat dan tantangan sekaligus. Dalam bidang pendidikan, digitalisasi telah menjadikan pembelajaran lebih efektif, efisien, dan interaktif. Di sisi lain, era 
digital telah menyebabkan terjadinya degradasi moral siswa (Sahronih, 2018). Keterbukaan informasi digital tanpa adanya bimbingan guru atau orang tua menyebabkan siswa mudah terpengaruh dengan informasi yang tidak benar. Karena misinformasi, siswa melakukan tindakan-tindakan amoral, misalnya perundungan, tawuran antarpelajar, rasisme, pornografi, bahkan tindak kriminal (Prihatmojo \& Badawi, 2020; Sari \& Bermuli, 2021).

Pencegahan kemerosotan moral yang semakin parah dapat dilakukan dengan mengintegrasikan pendidikan karakter yang sesuai dengan budaya, kepribadian bangsa, dan kebutuhan jaman dalam pembelajaran (Agung, 2011; Ferdiawan \& Putra, 2013; Ghufron, 2010; Walker, Roberts, \& Kristjánsson, 2015). Penguatan pendidikan karakter dalam pembelajaran telah dicanangkan oleh pemerintah dengan merumuskan lima nilai pendidikan utama, yaitu Religius, Nasionalis, Mandiri, Gotong Royong, dan Integritas (Kemendikbud, 2017). Pembelajaran sejarah sebagai usaha pembentukan jiwa manusia dapat diintegrasikan dengan pendidikan karakter yang kontekstual dengan basis pencarian makna referensial, yaitu hubungan antara teks dengan dunia luar (Ali, 2005; Hariyono, 2018).

Dalam pencarian makna referensial diperlukan teks yang dapat merefleksikan nilai karakter sekaligus peristiwa kesejarahan. Maka, dipilihlah novel sejarah. Chauhan (2013) mendefinisikan novel sejarah sebagai novel yang menggunakan latar periode sejarah tertentu sekaligus berusaha untuk menyampaikan semangat, perilaku, dan kondisi sosial dari masa lalu dengan detail dan kredibel terhadap fakta sejarah. Novel sejarah menurut Lukacs (1989) harus mampu mengakomodasikan realitas sosial yang berkembang di masyarakat. Sebagai bahan literasi, novel sejarah berperan penting dalam pendidikan di era globalisasi budaya demi menguatkan akar kebangsaan (Djokosujatno, 2010). Salah satu novel sejarah Indonesia yang representatif adalah Roro Mendut versi Y. B. Mangunwijaya. Novel ini menekankan permasalahan psikologis yang dialami oleh karakter yang beranjak dewasa sehingga cocok untuk dijadikan bahan refleksi siswa SMA setingkat.

Penelitian yang dilakukan oleh Ningsih \& Ediyono (2018) dan Utami, Warto, \& Sariyatun (2018) menunjukkan bahwa karya sastra klasik memiliki muatan nilai pendidikan karakter. Sedangkan, sastra kontemporer yang diteliti oleh Irma (2018), Wardani (2018), dan Afandi (2020) selain memuat nilai pendidikan karakter juga mampu membentuk karakter siswa. Namun, tidak semua bahan penelitiannya menggunakan setting kesejarahan sehingga belum ada pembahasan terkait dengan muatan historis. Selain itu, penelitian-penelitian tersebut belum menunjukkan adanya relevansi nilai dengan tantangan kehidupan modern. Oleh karena itu, penelitian ini bertujuan untuk mendeskripsikan muatan historis dan nilai-nilai pendidikan karakter, kemudian menjelaskan relevansinya terhadap fenomena di era digital.

\section{METODE}

Metode penelitian ini adalah kualitatif. Sumber data penelitian berupa buku cetak, yakni novel sejarah karya Y. B. Mangunwijaya dengan judul Roro Mendut dengan jumlah 400 halaman. Novel yang digunakan adalah cetakan pertama PT. Gramedia tahun 1983. Pengumpulan data 
dilakukan secara studi pustaka pada ciri tanda dalam teks menurut van Zoest (1990) yang terdiri dari ikonitas, simbolitas, dan kontigensi. Teknik analisis yang dipakai adalah semiologi Ferdinand de Saussure. Semiologi a la Ferdinand de Saussure adalah model semiotik yang mula-mula mengkaji tanda dengan teori sastra sehingga sesuai dalam pengkajian teks sastra (Lutfi, 2009). Bahasa dalam teks novel dipahami sebagai sebuah tindak komunikasi. Hubungan antara dikotomi tanda Saussure, signifier dan signified, dengan realitas eksternal merupakan proses pemaknaan tanda (signification) (Fiske, 1990; Saussure, 1959). Penelitian semiotik sering kali mengikuti garis besar langkah analisis data interpretativisme, tentunya dengan penekanan khusus dan variasi yang disesuaikan (Miles \& Huberman, 1994: 8). Oleh karena itu langkah-langkah penelitian ini meliputi, Identifikasi TandaInterpretasi Tanda-Penarikan Simpulan/Makna.

\section{HASIL DAN PEMBAHASAN}

\section{Sinopsis Novel Roro Mendut versi Y.B. Mangunwijaya}

Bermula dari desa nelayan yang damai di pesisir Kadipaten Pati, Telukcikal. Hari-hari damai melaut Roro Mendut harus berakhir karena ia dipilih tanpa kehendaknya menjadi selir Adipati Pragolo, penguasa Pati. Belum lama tinggal di Keputrian Puri Pati, Roro Mendut lantas menjadi putri rampasan untuk dipersembahkan kepada Susuhunan Hanyokrokusumo di Karta, Mataram setelah serangan yang dipimpin oleh Tumenggung Wiroguno berhasil memporak-porandakan Pati-yang ketahuan tengah mempersiapkan perlawanan terhadap Mataram. Sebagai putri rampasan dari negara bawahan yang kalah dalam pertempuran, hidup Roro Mendut sepenuhnya berada dalam kehendak Susuhunan sendiri.

Tumenggung Wiroguno terkesima dengan sosok Roro Mendut sejak pertemuan mereka kali pertama — saat Roro Mendut berusaha mati-matian membebaskan dirinya dari benteng Puri Pati. Pada akhirnya, Tumenggung Wiroguno meminta Susuhunan untuk 'menganugerahkan' Roro Mendut kepadanya. Namun, Roro Mendut secara konsisten menolak pinangan Tumenggung Wiroguno. Merasa terhina, Tumenggung Wiroguno membebankan sejumlah uang sebagai pajak Roro Mendut. Roro Mendut dan para dayangnya kemudian menjual putung rokok di pasar. Usaha Roro Mendut sukses besar. Diantara keramaian yang menjejali lapak Roro Mendut, Roro Mendut bertemu dengan Pronocitro.

Roro Mendut-Pronocitro yang sudah menjadi pasangan kekasih memulai rencana kemerdekaan Roro Mendut dari tembok Puri Wirogunan dan memulai hidup baru bersama. Malam pelarian diri mereka telah berhasil. Sayangnya, dalam perjalanan mereka menuju pesisir utara, mereka tertangkap oleh pasukan Tumenggung Wiroguno. Duel keris antara Pronocitro dan Tumenggung Wiroguno tak bisa dihindarkan. Tumenggung Wiroguno berhasil menikam Pronocitro. Ketika hendak menikamkan kerisnya untuk kali kedua, Roro Mendut spontan maju, tertusuk keris Tumenggung Wiroguno. Jasad keduanya kemudian terlarung bersama dibawa ombak samudera selatan.

\section{Muatan Historis}


Konflik terbuka antara Pati dan Mataram pada 1627 menjadi setting awal novel. Pada awal pendirian Mataram, Pati diikat dengan hubungan perkawinan bukan karena sebuah penaklukan. Dari sudut pandang Pati, kedudukannya sama dengan Mataram. Perspektif ini diteruskan sampai pemerintahan Adipati Pragolo II. Adipati Progolo menolak untuk sebha pada Grebeg Mulud 1627 M menghadap Susuhanan Hanyokrokusumo, padahal sebha adalah simbol loyalitas negeri bawahan kepada penguasa Mataram sebagai kerajaan induk (Sapto, 2017). Tentu Mataram memiliki perspektif yang berbeda dengan Pati. Ikatan perkawinan tersebut sudah diperbarui dengan pernikahan Adipati Pragolo II dengan adik Susuhunan Hanyokrokusumo. Bagaimanapun juga, Adipati Pragolo II tidak mengidentifikasikan dirinya sebagai penguasa vasal di bawah Mataram. Adipati Pragolo II menggalang dukungan dari faksi-faksi yang tidak puas dengan Mataram dan mempersiapkan penyerangan di wilayah pesisir utara (Pigeaud \& de Graaf, 1976). Konfrontasi militer antara Pati dan Mataram pun tidak bisa lagi dihindari. Mataram menang atas Pati, Kadipaten Pati dihancurleburkan, dan keluarga Adipati Pragolo II dibantai.

Dalam novel Roro Mendutnya, Romo Mangun berusaha menarasikan peristiwa sejarah tersebut dari sudut pandang yang berbeda. Alih-alih disebabkan oleh konflik kepentingan elit penguasa semata, Romo Mangun seolah-olah membuka kemungkinan alasan yang baru, dengan narasi yang bernuansa desas-desus yakni Adipati Pragolo II mempersiapkan perlawanan karena adanya kebijakan semena-mena Mataram kepada rakyat Pati (Kutipan 1). Selain itu, dalam novel ini lebih dititikberatkan pada sudut pandang rakyat kecil yang tengah diseret dalam konflik ini (Kutipan 2 dan 3).

Kutipan 1

Kata orang, Adipati Mataram terkena marah Susuhunan Mataram. Ada yang mengatakan beliau (Adipati Pragolo) memberontak..., karena rakyatnya dihisap berasnya demi persiapan serangan Betawi oleh Susuhunan Hanyokro-Kusumo. Sang Adipati tak mau menghadap istana di Karta (Mangunwijaya, 1983: 11-12).

Kutipan 2

Itu urusan orang-orang darat, begitu selalu Siwo menanggapi berita-berita sejenis itu. Itu thethekmbengek orang-orang Selatan...Tetapi tentulah Siwo hanya berani omong itu di dalam hati. Sebab setiap raut muka yang menandakan celaan sedikit saja melawan Raja, dapat mahal harganya: kepala orang (Mangunwijaya, 1983: 12).

Kutipan 3

Mengapa orang-orang gedhe itu tidak berkelahi saling melabrak di tempat yang jauh saja, menjauhi kedamaian kaum pantai yang terus terang saja tidak pernah merasakan hubungan batin serambut pun dengan orang-orang pedalaman, biar berpangkat raja agung sekalipun. Guna apa orang-orang asing itu datang kemari?...Pajak baru barangkali?...Cuma minta ini, merampok itu. Kalau begitu apa bedanya: raja dengan benggolan penyamun? (Mangunwijaya, 1983: 15).

Alur cerita di dalam novel kemudian menceritakan persiapan Mataram mengadakan serangan ke Batavia. Persiapan penyerang ke Batavia telah dipersiapkan Mataram sejak 
kejatuhan Surabaya pada 1625. Setelah persiapan yang panjang itu, akhirnya pasukan Mataram siap, pada Agustus dan Oktober 1628 pasukan pertama dan kedua Mataram tiba di Batavia setelah menempuh perjalanan sepanjang $500 \mathrm{~km}$ (Ricklefs, 2009). Pasukan pertama dipimpin oleh Tumenggung Bahureksa sementara pasukan kedua dipimpin oleh Tumenggung Mandurorejo dengan total sekitar 10.000 prajurit.

Persiapan penyerangan ke Batavia tidak banyak mempengaruhi alur cerita. Peristiwa ini sempat disinggung sebagai penyebab perlawanan Adipati Pragolo (Kutipan 1). Namun demikian, Romo Mangun berusaha menghadirkan fakta-fakta sejarah terkait persiapan tersebut sebagaimana ditunjukkan pada Kutipan 4 sampai Kutipan 6.

Kutipan 4

Sudah bertubi-tubi kaum VOC blasteran rase itu diundang, tetapi nekad buto-buto rambut jagung itu membangkang. Sesudah Pathi, Betawi harus digebuk... (Mangunwijya, 1983: 176)

Kutipan 5

Hormat Wiroguno tersenyum kepada Tumenggung Mandurorejo yang rupa-rupanya akan mendapat kehormatan...memimpin barisan-barisan Mataram menyerang Betawi (Mangunwijaya, 1983, 90).

Kutipan 6

...sebentar lagi beberapa utusan duta besar utusan Raja Panembahan ratu dari Cirebon akan datang. Maka Sri Baginda bertitah untuk mempersiapkan acara Sodoran Seton secara istimewa...duta-duta itu harus diyakinkan betapa kuatnya balatentara Mararam. Sebab Cirebon selalu ragu dan sikap plin-plan meminta 'perlindungan' dari VOC.

Selain penggunaan latar peristiwa sejarah khusus, novel sejarah Roro Mendut juga berusaha mengangkat kondisi kehidupan masyarakat pada masa lalu. Kondisi masyarakat yang menjadi isu yang signifikan di dalam novel adalah peran dan kedudukan perempuan dalam masyarakat Mataram Islam. Perempuan-perempuan bangsawan memiliki hak keuangan yang kuat terutama hak atas tanah dan jabatan sehingga mereka masih memilki kemandirian secara finansial yang menjamin kehormatan mereka di lingkup keluarga masing-masing (Carey \& Houben, 2016). Hak atas tanah lungguh (tanah jabatan) ini disebutkan oleh Romo Mangun dalam novelnya sebagaimana dalam Kutipan 7 berikut.

Kutipan 7

"Coba, sekarang wedono-lebet macam Suwitoprojo itu di istana Raja menerima tanah lungguh 5000 karya dan di Wirogunan 4000 karya, sedangkan seorang ratu kencana hanya 1000 karya.

Putra mahkota bertanah lungguh 8000 karya..." (Mangunwijaya, 1983: 297).

Dalam Kutipan 7 tersebut Romo Mangun menyoroti bahwa Ratu Kencana atau permaisuri raja menerima sejumlah tanah namun jumlahnya masih jauh daripada pejabat pria. 
Meskipun memiliki jatah keuangan yang lebih kecil dibanding pria, faktanya perempuan jawa baik ningrat maupun rakyat biasa memiliki andil besar dalam pengeloaan keuangan dibandingkan dengan pria. Seperti catatan Raffles yang dikutip Carey \& Houben (2016: 37-38) berikut.

Dalam hal urusan keuangan, perempuan (Jawa) secara universal dianggap unggul dibandingkan pria, dan dari buruh umum sampai kepala provinsi sudah lumrah suami mempercayakan urusan uang sepenuhnya kepada istrinya... Ada pepatah bahwa pria (Jawa) sama sekali tolol dalam hal keuangan.

Serupa catatan Raffles tersebut, Romo Mangun juga menjelaskan hal yang sama. Kompetensi manajemen keuangan perempuan Jawa secara umum yang diakui seperti Kutipan 8 berikut.

Kutipan 8

Tetapi seandainya mereka punya waktu lebih banyak untuk berkeliling, pastilah mereka dapat mencatat, bahwa seluruh rumah tangga Kerajaan Mataram pada hakikatnya tidak dijalankan oleh para jago jantan, tetapi olah ubed-nya kaum wanita (Mangunwijaya, 1983: 203).

Hak dan kompetensi finansial yang diakui, rupanya tidak sebanding dengan peran publik perempuan utamanya bidang birokrasi. Hampir setiap pejabat publik Mataram adalah laki-laki. Kecuali adanya prajurit estri atau prajurit perempuan yang khusus mengawal raja. Rekaman Rijklof van Goens (dalam Kumar, 1980) yang mengunjugi Mataram ca. 1648-1654, menjelaskan keberadaan sepasukan perempuan sekira berjumlah 150 orang dengan tugas pembawaan masing-masing menyertai Susuhunan ketika sedang miyos, sedangkan sekitar 20 orang membawa tombak dan senapan, menjaga raja di seluruh sisi. Para pengawal raja ini tidak hanya dilatih keterampilan bersenjata dan bela diri namun juga menari, menyanyi, dan memainkan gamelan. Keberadaan prajurit perempuan ini disebutkan oleh Romo Mangun mirip seperti yang dijelaskan oleh van Goens seperti pada Kutipan 9 berikut.

Kutipan 9

Disebelah kanan kiri raja berbarislah tiga puluh orang pendekar wanita muda cantik segagah Srikandi. Empat dengan tombak berkampak, dan enam belas dara siaga dengan senapan api di sekitar (Mangunwijaya, 1983: 94).

Kecuali kemampuan manajemen yang dimiliki perempuan Jawa secara umum, rupanya hak ekonomis dan peran kemiliteran merupakan previlese yang hanya dapat dinikmati oleh perempuan Jawa ningrat saja. Hal ini barangkali disebabkan karena dalam masyarakat Asia Tenggara dan Jawa khususnya status merupakan hal yang lebih diutamakan daripada gender (Reid, 1988). Perempuan rakyat lebih berperan dalam urusan domestik dan bersama-sama suami mengurus lahan pertanian atau peternakan mereka. Selebihnya baik perempuan maupun lakilaki harus tunduk pada penguasa feodal. Belum lagi perempuan-perempuan korban perang dengan status hasil jarah-rayah harus pasrah sepenuhnya kepada keputusan pemenang perang. Roro Mendut misalnya, merupakan contoh perempuan rakyat yang kemudian menjadi perempuan rampasan yang oleh Romo Mangun dilukiskan selalu menjadi subyek hegemoni pria 
bangsawan. Pertama, ia ditunjuk begitu saja sebagai selir Adipati Pragolo (Kutipan 10), lalu setelah kekalahan melawan Mataram ia diminta oleh Tumenggung Wiroguno sebagai hadiah dari Susuhunan Hanyokrokusumo selaku pemenang perang (Kutipan 11).

Kutipan 10

Tersembah bahagia Raden Roro Mendut! Yang terjunjung Adipati Pragolo, sang keris penguasa wilayah Pathi termahsyur telah berkenan pada Roro Mendut, dan memanggil Roro Mendut sebagai belahan jiwa di istana (Mangunwijaya, 1983: 18).

Kutipan 11

Insya Allah, gadis Mendut itulah yang ingin Wiroguno mohon nanti kepada Sri Baginda (Mangunwijaya, 1983: 90).

\section{Muatan Nilai Pendidikan Karakter}

\section{Religius}

Religiusitas tokoh-tokoh dalam novel Roro Mendut dibangun oleh Y.B. Mangunwijaya sesuai dengan kondisi kehidupan keagamaan pada masa Mataram Islam. Meskipun Islam telah menjadi agama yang banyak disebarkan dan dianut oleh masyarakat Jawa, nyatanya masyarakat pedalaman masih menghayati kepercayaan Jawa pra-Islam, Kejawen (Koentjaraningrat, 1980). Berbeda dengan masyarakat pesisir utara Jawa yang telah berada dalam pengaruh Islam yang kuat karena kontak perdagangan yang masif dan disertai dengan upaya islamisasi di bandarbandar pesisir utara Jawa (Robson, 1981).

Tokoh dengan keimanan Islam yang mapan banyak digambarkan melalui tokoh pesisir utara seperti pada Kutipan 12 sampai Kutipan 14.

Kutipan 12

Ya, Allah Maha Pengasih. Sesungguhnya kebahagiaan tidak selalu melalui pintu rahim sendiri. Buah-buah kandungan wanita-wanita lain pun. Terutama yang piatu dan terlantar, bukankah itu dapat menjadi titipan Allah Yang Mahabijaksana, yang tidak kalah nikmat, sumber syukur dan pemekaran diri seorang wanita? (Mangunwijaya, 1983: 46).

Kutipan 13

Berkat Rahmatullah segala kemajuan perusahaan kapal kita (Mangunwijaya, 1983: 214).

Kutipan 14

Ah, Mbak, bukan kami yang berjasa. Cinta jodoh selalu rahmat Allahirahmanirahim (Mangunwijaya, 1983:357).

Kutipan-kutipan di atas menunjukkan ketaqwaan pemeluk agama Islam. Kutipan 12 dan 13 masing-masing merupakan pemikiran yang dimiliki oleh Ni Semongko dan Nyai Singobarong. Keduanya berasal dari pesisir utara, Pathi dan Pekalongan. Dalam kutipan-kutipan tersebut 
terlihat bagaimana mereka berdua mensyukuri karunia (sekalipun sangat berbeda bentuknya) yang mereka miliki yang tidak lain berasal dari Allah SWT. Sementara Kutipan 14 adalah ucapan Roro Mendut-juga berasal pesisir utara, yang mencerminkan keimanan kepada nasib dan takdir yang berada di tangan Allah SWT.

Sedangkan tokoh yang merepresentasikan masyarakat pedalaman Mataram yang digambarkan mempraktikkan tradisi Kejawen adalah Nyai Ajeng dan Susuhunan Hanyokrokusumo. Nyai Ajeng berdoa kepada entitas supranatural yang ia imani ketika tengah dalam kesulitan (Kutipan 15). Sedangkan, Susuhunan bersyukur atas kemengangan atas Pathi yang baru saja ia peroleh (Kutipan 16).

Kutipan 15

Ah, perlu, sangat perlu Nyai Ajeng berdoa. Kepada Dewi Sri, kepada Dewi Ratih, dan ah... kepada citra ibu dari ibu, rahim yang pernah mengemban Panca-Batara, Dewi Umayi. (Mangunwijaya, 1983: 354)

Kutipan 16

...langkah-langkah tenang sang raja perlahan-lahan melangkah dari senthong tengah yang keramat, yang dikhususkan untuk menghormati Dewi Sri dan dewa-dewi kesuburan Kama-Jaya serta Kama-Ratih, tempat simpanan pusaka-pusaka kerajaan juga, di mana sang raja baru saja bersemedi mengucapkan syukur pribadi atas kemenangan Mataram terhadap Pathi. (Mangunwijaya, 1983: 94)

Meskipun memiliki perbedaan kepercayaan namun nilai religiusitas keduanya sama. Para penganut masing-masing kepercayaan menjalankan ritus agamanya masing-masing, beriman kepada kebesaran Tuhan masing-masing, serta bersyukur dan berdoa kepada-Nya. Dalam novel juga tidak ditemukan adanya konflik dengan alasan perbedaan agama. Hal ini sejalan dengan definisi nilai karakter religius menurut Kemendikbud (2017) yang diidentifikasikan dengan keberimanan terhadap Tuhan, agama dan kepercayaan yang dianut, menghargai perbedaan agama, menjunjung tinggi sikap toleran terhadap pelaksanaan ibadah agama dan kepercayaan lain, hidup rukun dan damai dengan pemeluk agama lain

\section{Nasionalis}

Nilai cinta tanah air dimunculkan oleh Y.B. Mangunwijaya melalui dua alasan fundamental yang berbeda. Dua alasan itu dimiliki oleh Tumenggung Wiroguno dan Adipati Pragolo, yang berhadap-hadapan dalam medan perang. Adipati Pragolo bersedia berperang demi melindungi kepentingan rakyatnya yang menderita karena pajak yang ditetapkan oleh pemerintah pusat kerajaan terlalu besar (Kutipan 19). Sedangkan, Tumenggung Wiroguno bersedia mengorbankan segalanya untuk negaranya karena kesetiaan yang kuat terhadap raja dan kejayaan negaranya (Kutipan 20).

Kutipan 19 
Ada yang mengatakan beliau (Adipati Pragolo) memberontak, mengulangi permusuhan ayahnya almarhum melawan Panembahan Senapati nun dulu, karena rakyatnya dihisap berasnya demi persiapan serangan Betawi oleh Susuhunan Hanyokro-Kusumo (Mangunwijaya, 1983: 11).

Kutipan 20

Ya, demi kejayaan Mataram dan demi kemuliaan sang raja lah Wiroguno mempersembahkan hidup dan jasanya. Hidup asmaranya juga (Mangunwijaya, 1983: 85).

Kedua alasan tersebut bertolak belakang satu sama lain namun bobot kecintaan terhadap tanah airnya sama. Adipati Pragolo berusaha melindungi hak-hak rakyatnya sedangkan Tumenggung Wiroguno menunjukkan loyalitas terhadap kepentingan bangsanya. Keduanya menunjukkan sikap dan tidankan yang mencerminkan nasionalitas sesuai peran masing-masing, Adipati Pragolo adalah penguasa daerah yang bertanggung jawab terhadap kepentingan rakyatnya sedangkan Tumenggung Wiroguno adalah pimpinan militer yang harus selalu siap sedia membela negaranya apapun alasan dan resikonya. Hal itu adalah bagian dari sikap cinta tanah air yang diwujudkan dengan pemikiran, sikap, dan perbuatan yang menunjukkan kesetiaan, kepedulian, dan penghargaan yang tinggi terhadap bahasa, lingkungan fisik, dan politik bangsa, menempatkan kepentingan bangsa dan negara di atas kepentingan diri dan kelompoknya (Kemendikbud, 2017).

\section{Mandiri}

Nilai Mandiri adalah sikap dan perilaku yang tidak mudah tergantung pada orang lain dalam menyelesaikan tugas-tugasnya (Kemendikbud, 2017). Dalam novelnya, Y.B Mangunwijaya menghadirkan tokoh-tokoh perempuan mandiri di tengah masyarakat Mataram yang didominasi oleh peran pria. Kemandirian tokoh-tokoh perempuan ini mencerminkan perjuangan perempuan mencapai kesetaraan dan mendapatkan haknya seperti pada Kutipan 21 dan Kutipan 22.

Kutiapan 21

Maka berlarilah si Mendut itu, lalu memanjat dinding keputrian. Mendut sendiri bercerita sesudahnya, bahwa pada saat itu ia memang mati-matian untuk lari dari puri dan bertekad pulang ke desanya, entah bagaimana caranya (Mangunwijaya, 1983: 48).

Kutipan 22

Mendut sendiri dengan dayang-dayangnya di belakang tirai tanpa beristirahat melayani nafsu para penghisap puntung (Mangunwijaya, 1983: 243).

Dua kutipan di atas merupakan sikap Roro Mendut dalam mengatasi situasi yang sedang dia alami. Roro Mendut berjuang mati-matian untuk membebaskan dirinya dari Puri Pathi karena ia masuk Puri Pathi dengan terpaksa (Kutipan 21). Apapun jalan yang harus ia tempuh, apapun resikonya, Roro Mendut berusaha sangat keras untuk mewujudkan keinganannya. Kutipan 22 juga memperlihatkan hal yang sama sebuah perjuangan dan usaha keras seorang Roro Mendut yang ingin mewujudkan kemerdekaannya, namun bedanya kali ini dari Puri Wirogunan. Dengan kreatif Roro Mendut memiliki ide untuk berjualan putung rokok di pasar. Usahanya pun sukses, 
ia bekerja setiap hari untuk memenuhi jumlah uang pajak yang dibebankan Tumenggung Wiroguno.

Karakater mandiri juga berhasil membuktikan kompetensi perempuan dalam bidang ekonomi. Keberhasilan Nyai Singobarong sehingga menjadi salah satu saudagar yang sukses tidak luput dari prinsip kemandiriannya. Dunia persaudagaran didominasi oleh kaum pria. Sekalipun menyadari dominasi pria dalam perniagaan besar, Nyai Singobarong tetap optimis dan berusaha hingga perusahaan dagangnya sukses besar. Keberhasilan Nyai Singobarong banyak menimbulkan rasa iri hati saudagar pria yang kalah dan tidak terima dengan kesukesan janda Nyai Singobarong. Kemandirian dan kesuksesaan Nyai Singobarong tergambar seperti Kutipan 23 berikut.

\section{Kutipan 23}

Tak kerasanlah sang janda saudagar di desa, lalu pulang ke kota, tempat tinggal suaminya almarhum, yakni seorang saudagar kapal ternama, kaya, dan yang telah mewariskan modal serta harta kepada istrinya,... Dan ternyatalah sang janda, Nyai Singobarong sebutannya, telah membuktikan diri sebagai wanita cerdas terampil dan penuh bakat kewiraswastaan yang disegani (atau dicemburui) rekan-rekan saudagar pria lain (Mangunwijaya, 1983: 204).

\section{Gotong Royong}

Gotong Royong merupakan ciri khas masyarakat Indonesia. Menurut Kemendikbud (2017) yang dimaksud nilai gotong royong adalah tindakan menghargai semangat kerjasama dan bahu membahu menyelesaikan persoalan bersama, menjalin komunikasi dan persahabatan, memberi bantuan/pertolongan pada orang-orang yang membutuhkan. Gotong royong didasarkan pada semangat dan kesadaran bahwa dengan bekerja sama, beban yang ditanggung akan menjadi ringan dan tujuan bersama semakin mudah diraih (Simarmata, Yuniarti, Riyono, \& Patria, 2020). Gotong Royong dalam novel Roro Mendut merupakan representasi dari kerja sama untuk mencapai sebuah tujuan bersama. Kerja sama yang kuat ini didorong selain karena adanya tujuan bersama yang ingin diraih juga didasari pada kedekatan sosial erat seperti yang tampak pada Kutipan 24 sampai Kutipan 26.

Kutipan 24

Yoh! Dorongan terakhir! Hono-hini-hayo-HING! (“Payah!” Gadis itu menggeleng-gelengkan kepala) Yoh! Hono-hiiniii-hayo......HENG! Haduh! Akhirnyalah perahu penuh ikan itu kandas di pasir (Mangunwijaya, 1983: 7).

Kutipan 25

Maka bersama sama dengan Gendhuk Duku dan beberapa abdi yang ternyata baik hati dan ikhlas merisikokan diri membantu sang putri boyongan yang membandel itu. Ni Semongko sudah berbelanja rokok dan segala perabot yang dibutuhkan oleh usaha puannya, Roro Mendut (Mangunwijya, 1983: 224). 
Kutipan 26

Prajurit dan dayang-dayang berbondong-bondong lari ke kandang kuda. Keputrian menjadi sepi. Lekas-lekas Putri Arumardi masuk ke gandhok-nya dan memberi tanda. Secepat badai, Roro Mendut dan Pronocitro yang oleh kewaspadaan Putri Arumardi disembunyikan dalam gandhoknya keluar....Tanpa menghamburkan secuil detik Mendut diangkat di atas kuda yang telah siap, dan berlarilah kedua kekasih itu ke dalam kegelapan malam. Ntir-untir dan Bolu cepat-cepat naik kuda masing-masing dan lari ke arah berlawanan (Mangunwijaya, 1983: 365).

Kutipan-kutipan di atas menunjukkan adegan gotong royong para tokoh dalam mengerjakan suatu hal. Kutipan 24 memperlihatkan bagaimana Roro Mendut, Siwo, dan Slamet tengah berusaha untuk melabuhkan kapal mereka di pantai. Kutipan 25 menunjukkan bantuan yang diberikan oleh abdi Wirogunan kepada Ni Semongko dan Genduk Duku ketika berbelanja kebutuhan berjualan rokok. Sedangkan kutipan 26, menceritakan proses pembebasan Roro Mendut-Pronocitro yang melibatkan kerja sama dan dukungan banyak pihak, diantaranya Putri Arumardi dan dua abdi Pronocitro. Kesamaan lain yang menjelaskan terjadinya gotong royong tersebut digerakkan oleh karena ikatan batin yang kuat, rasa empati, dan kebutuhan saling menolong. Semua pekerjaan yang dikerjakan dengan gotong royong dalam kutipan-kutipan tersebut maupun adegan dalam novel lainnya, dapat berhasil dengan baik

\section{Integritas}

Dalam Kemendikbud (2017: 9) yang dimaksud nilai karakter integritas adalah nilai yang mendasari upaya menjadikan dirinya sebagai orang yang selalu dapat dipercaya dalam perkataan, tindakan, dan pekerjaan, memiliki komitmen dan kesetiaan pada nilai-nilai kemanusiaan dan moral (integritas moral). Integritas ditunjukkan dengan sikap dan tindakan dimanapun dia berada, dan kondisi apa pun yang menekannya, ia tetap hidup konsisten dengan nilai-nilai yang dianutnya (Gea, 2006). Beberapa contoh sikap integritas dalam novel dapat dilihat pada Kutipan 27 hingga Kutipan 29.

Kutipan 27

Untunglah ada Ni Kuweni, dayang pribadinya yang sampai sekarang tergolong satu dari sedikit wanita terpercaya yang diperkenankan masuk ruang-ruang pribadi Wiroguno, bahkan menolong Wiroguno dalam acara mandi dan berbusana (Mangunwijaya, 1983: 109).

Kutipan 28

Berat rasanya tanggung jawab menekan di dalam dadanya. Dalam hati ia kagum dengan gadis pantai itu. Ini wanita yang benar-benar punya kepribadian. Tetapi suaminya harus ditolong juga martabatnya (Mangunwijaya: 1983: 354).

Kutipan 29

Akan kularikan kau ke pantai-pantai merdeka... Tekadku sudah bulat. Dan tanggung jawabku adalah kehormatanku (Mangunwijaya, 1983: 322).

Pada kutipan 27 menunjukkan integritas yang dimiliki Ni Kuweni selama bekerja sebagai dayang di Puri Wirogunan. Dengan kejujuran dan integritasnya itu, Ni Kuweni berhasil menjadi 
dayang kepercayaan yang diberi tugas-tugas khusus. Kutipan 28 dan 29 merepresentasikan tokoh-tokoh yang selalu memiliki komitmen dan prinsip dalam menjalankan peran dan menepati janjinya. Tokoh pada Kutipan 28 adalah Nyai Ajeng yang dengan segala cara berusaha menyelamatkan martabat suaminya sekaligus ingin Roro Mendut berbahagia. Jadi ia memikirkan win-win solution dengan membebaskan Roro Mendut sekaligus menyelamatkan harga diri suaminya yang turun karena penolakan-penolakan Roro Mendut. Sedangkan Pronocitro pada Kutipan 29, menunjukkan kebulatan tekadnya untuk membebaskan Roro Mendut dari Wirogunan sesuai dengan janjinya setelah mereka berdua menjadi sepasang kekasih. Kebulatan tekad ini diwujudkan dengan siasat Pronocitro yang berlagak melamar pekerjaan di Wirogunan supaya diijinkan tinggal di dalamnya dan memudahkan usaha pembebasan Roro Mendut. Sekalipun Pronocitro sadar akan resiko yang menantinya, ia menunjukkan integritasnya sebagai seorang yang berjiwa kesatria.

\section{Relevansi di Era Digital}

Muatan historis dalam novel menunjukkan hasil pembacaan yang cermat dan berimbang dari penulis. Banyak fakta-fakta sejarah yang ditulis oleh Romo Mangun dalam novelnya sesuai dengan tulisan sejarawan dalam buku-buku sejarah. Romo Mangun juga berusaha menulis ulang sejarah melalui sudut pandang kawula alit atau rakyat kecil yang selama ini luput dalam penulisan sejarah. Hal ini merefleksikan kecermatan dan pemikiran yang kritis dalam menanggapi suatu wacana. Dalam era digital ini kemampuan berpikir kritis dalam membaca informasi yang beredar bebas di media sosial menjadi sangat penting dalam mencegah misinformasi yang cenderung membuat remaja berperilaku amoral. Kemampuan ini juga patut disertai dengan kecermatan dalam memilih sumber-sumber informasi kredibel untuk dikonsumsi di era digital.

Nilai religius dalam novel dapat digunakan sebagai bahan refleksi dalam menghadapi ancama disintegrasi karena hoaks isu agama. Nilai religius yang digambarkan dalam novel direpresentasikan oleh dua penganut keimanan yang berbeda. Meskipun berbeda, religiusitas keduanya sama. Mereka berdoa, bersyukur, memasrahkan diri pada entitas yang mereka imani melalui tata cara masing-masing. Perbedaan tata cara peribadatan tidak pernah menjadi alasan timbulnya konflik. Hikmahnya bahwa menjadi religius tidak lantas antipati tehadap umat agama lain. Justru dengan religiusitas mendorong tumbuhnya rasa saling menghargai dan mewujudkan masyarakat yang rukun.

Nasionalisme yang dapat ditiru dari novel Roro Mendut adalah cinta tanah air yang humanis yang didasarkan pada keadilan dan martabat manusia. Romo Mangun menggambarkan kecintaan Adipati Pragolo terhadap tanah airnya melalui keberanian melawan Mataram yang memungut pajak sangat besar dan menyebabkan penderitaan rakyat Kadipaten Pati. Namun, loyalitas Tumenggung Wiroguno terhadap negaranya juga bukan merupakan hal yang salah. Seperti Kumbakarna dengan jiwa besar maju perang membela negaranya, loyalitas yang penuh terhadap kepetingan bangsa merupakan cerminan jiwa kesatria. Oleh sebab itu, di era digital ini, dimana pengaruh berbagai macam ideologi masuk, loyalitas terhadap ideologi bangsa dan keinginan untuk meraih suatu masyarakat yang berkeadilan, berperikemanusiaan, dan sejahtera patut untuk ditanamkan pada generasi penerus bangsa. 
Perkembangan e-commerce yang pesat disertai berbagai tawaran diskon dan masifnya promosi memunculkan tekanan untuk sukses secara finansial sejak muda. Tekanan yang begitu kuat namun kurangnya karakter justru memicu tindak kriminalitas. Dibutuhkan refleksi nilai mandiri dan integritas. Nilai mandiri akan mendorong siswa untuk mampu memikirkan upayaupaya mencapai keinginannya tanpa bergantung pada orang lain dan kesadaran bahwa diperlukan usaha untuk mencapai suatu yang diharapkan. Nilai integritas akan membentengi siswa dari tindakan-tindakan kriminal yang dapat merugikan orang lain dan menjamin kepatuhan terhadap nilai-nilai moral dalam masyarakat.

Digitalisasi yang masif di segala bidang menuntut kolaborasi yang kuat antarsegmen masyarakat. Prinsip kolaborasi sama dengan prinsip nilai gotong royong. Kerja sama yang dibangun dengan prinsip gotong royong akan menghasilkan hubungan yang mutual, saling menguntungkan. Selain itu, dengan nilai gotong royong, orientasi yang dituju bukan hanya sekadar pencapaian hasil semata namun membangun hubungan sosial yang erat dalam berproses bersama. Seperti yang direpresentasikan dalam novel bahwa gotong royong mampu membawa hasil yang baik karena setiap orang yang terlibat diikat suatu kedekatan sosial yang erat.

\section{SIMPULAN}

Temuan muatan historis dalam novel ini menunjukkan bahwa Romo Mangun berusaha menulis novel sejarah dengan memperhatikan kredibilitas latar kesejarahan yang mengiringi alur cerita. Banyak kesesuaian peristiwa sejarah serta gambaran kehidupan masyarakat, terutama peranan perempuan di tengah Mataram yang patriarkis. Romo Mangun juga berusaha menampilkan sejarah yang dengan perspektif yang lain. Bila selama ini penulisan sejarah prakolonial selalu berfokus pada elit-elit keraton, Romo Mangun berusaha menyajikannya dalam sudut pandang orang-orang yang tertidas karena terseret dalam konflik kepentingan para elit, rakyat biasa dan perempuan misalnya. Kemudian, Romo Mangun berusaha menyajikannya secara berimbang, Konflik Pati yang kebanyakan selalu dilihat sebagai sebuah pemberontakan dari sudut pandang Mataram, dinarasikan sebagai sebuah kecintaan terhadap tanah air dari Adipati Pragolo yang ingin memperjuangkan status kedaulatan tanahnya. Selain itu, dimunculkan sebuah alternatif baru dalam melihat konflik ini sebagai suatu pembelaan terhadap rakyat Pati yang banyak menderita karena pungutan pajak Mataram.

Nilai religius dalam novel ini memperlihatkan sebuah tatanan masyarakat yang mampu hidup rukun di tengah perbedaan. Menjadi religius bukan hanya sekadar bertaqwa kepada Tuhan Yang Maha Kuasa namun juga pilihan hidup untuk berani merasa empati dan saling menghargai satu sama lain sekalipun berbeda keyaninan. Nilai nasionalis yang direpresentasikan dalam novel memperlihat dua tokoh yang saling berhadapan dalam konfrontasi terbuka. Keduanya memiliki alasan yang kuat dalam membela kepentingan negara masing-masing. Dari sudut manapun dipandang nasionalitas keduanya merupakan hal sudah sepatutnya mereka lakukan sebagai ciri watak kesatria. Nilai mandiri dalam novel ini banyak digambarkan melalui tokoh-tokoh dengan 
determinasi tinggi. Dalam masyarakat yang patriarkis kemandirian mereka mampu menunjukkan kesetaraan derajat dan kompetensi mereka. Nilai gotong royong dalam novel ini menjukkan ciri karakter khas masyarakat Indonesia yang gemar bekerja sama yang didasari pada keintiman sosial, kesadaran untuk saling menolong dan semangat meraih tujuan bersama. Integritas sebagai nilai yang terakhir merupakan gambaran dari kepatuhan terhadap prinsip-prinsip moral dan komitmen dari setiap tanggung jawab yang dimiliki.

Muatan historis dan nilai pendidikan karakter dalam novel ini memiliki relevansi sebagai bahan literatur pembelajaran sejarah yang mengintegrasikan nilai pendidikan karakter. Sebagai novel sejarah dengan latar abad ke-17, novel ini menyediakan informasi kebijaksanaan masa lalu sebagai pedoman untuk menyikapi tantangan era digital. Kearifan masa lalu yang tergambar dalam novel mencirikan karakter khas Indonesia yang memiliki empati sosial yang tinggi, kepatuhan terhadap nilai agama dan moral, berwatak kesatria, dan pekerja keras. Sikap-sikap itu, yang mulai luntur dalam derasnya arus digitalisasi dapat dibangkitkan kembali melalui pembelajaran sejarah di kelas yang memanfaatkan teks sastra, salah satunya novel, sebagai bahan menggali kebijaksanaan dan nilai karakter dari peristiwa dan pemikiran masa lalu. Lebih lanjut, diperlukan metode khusus untuk mengaplikasikan nilai pendidikan karakter dalam novel sejarah pada pembelajaran sejarah di sekolah. Dengan demikian diharapkan terwujud pembelajaran sejarah yang kontekstual yang mampu memperkaya literasi siswa, mendorong siswa berpikir kritis, dan dapat merefleksi hikmah masa lalu sebagai pedoman menentukan sikap ke depan.

\section{DAFTAR RUJUKAN}

Afandi, I. (2020). The Character Value in The Fairy Tale "Cerita Calon Arang" By Pramoedya Ananta Toer as A Means of Early Childhood Education. Jurnal Pendidikan Karakter, 10(2). doi: 10.21831/jpk.v10i2.31973

Agung, L. (2011). Character Education Integration In Social Studies Learning. Historia: Jurnal Pendidik Dan Peneliti Sejarah, 12(2), 392-403. doi: 10.17509/historia.v12i2.12111

Ali, M. (2005). Pengantar Ilmu Sejarah Indonesia. Yogyakarta: LKiS.

Carey, P., \& Houben, V. (2016). Perempuan-Perempuan Perkasa di Jawa Abad XVIII-XIX. Jakarta: Kepustakaan Populer Gramedia.

Chauhan, Y. (2013, Oktober 3). Historical Novel. Diambil 24 Oktober 2019, dari Encyclopedia Britannica website: https://www.britannica.com/art/historical-novel

Djokosujatno, A. (2010). Novel Sejarah Indonesia: Konvensi, Bentuk, Warna, dan Pengarangnya. Hubs-Asia, 10(1). Diambil dari http://hubsasia.ui.ac.id/old/index.php/hubsasia/article/view/21

Dwivedi, Y. K., Hughes, D. L., Coombs, C., Constantiou, I., Duan, Y., Edwards, J. S., ... Upadhyay, N. (2020). Impact of COVID-19 pandemic on information management research and practice: Transforming education, work and life. International Journal of Information Management, 55, 102211. doi: 10.1016/j.ijinfomgt.2020.102211 
Ferdiawan, E., \& Putra, W. E. (2013). Esq Education for Children Character Building based on Phylosophy of Javaness in Indonesia. Procedia - Social and Behavioral Sciences, 106, 10961102. doi: 10.1016/j.sbspro.2013.12.123

Fiske, J. (1990). Introduction to Communication Studies (Studies in Culture and Communication) (2 ed.). London: Routledge.

Garad, A., Al-Ansi, A. M., \& Qamari, I. N. (2021). The Role of E-Learning Infrastructure and Cognitive Competence in Distance Learning Effectiveness During The Covid-19 Pandemic. Jurnal Cakrawala Pendidikan, 40(1), 81-91. doi: 10.21831/cp.v40i1.33474

Gea, A. A. (2006). Integritas Diri: Keunggulan Pribadi Tangguh. Character Building Journal, 3, 1626.

Ghufron, A. (2010). Integrasi Nilai-Nilai Karakter Bangsa Pada Kegiatan Pembelajaran. Jurnal Cakrawala Pendidikan, 1(3). doi: 10.21831/cp.v1i3.230

Hariyono, H. (2018). Pendidikan Sejarah dan Karakter Bangsa. Jurnal Pendidikan Sejarah Indonesia, 1(1), 1-22. doi: http://www.jurnalpsi.com/index.php/jpsi/article/view/7

Irma, C. N. (2018). Nilai-Nilai Pendidikan Karakter Dalam Novel Ibuk Karya Iwan Setyawan. RETORIKA: Jurnal Bahasa, Sastra, Dan Pengajarannya, 11(1), 14-22. doi: 10.26858/retorika.v11i1.4888

Kemendikbud. (2017). Konsep dan Pedoman Penguatan Pendidikan Karakter. Jakarta: Kementerian Pendidikan dan Kebudayaan.

Koentjaraningrat. (1980). Javanese Terms for God and Supernatural Beings and The Idea of Power. Dalam R. Schefold, J. W. Schoorl, \& J. Tennekes (Ed.), Man, Meaning and History (hlm. 127139). Brill. Diambil dari https://www.jstor.org/stable/10.1163/j.ctvbqs5km.9

Kumar, A. (1980). Javanese Court Society and Politics in the Late Eighteenth Century: The Record of a Lady Soldier. Part I: The Religious, Social, and Economic Life of the Court. Indonesia, (29), 1-46. doi: 10.2307/3351003

Lukacs, G. (1989). The Historical Novel (H. Mitchell \& S. Mitchell, Penerj.). London: Merlin Press. Lutfi, I. (2009). Semiotik dalam Telaah Hubung Prasasti dan Religi. Bahasa dan Seni, 30(2). Mangunwijaya, Y. B. (1983). Roro Mendut. Jakarta: Gramedia.

Miles, M. B., \& Huberman, A. M. (1994). Qualitative Data Analysis (2 ed.). London: Sage Publications.

Ningsih, Y. E., \& Ediyono, S. (2018). Nilai-Nilai Pendidikan Karakter Dalam Serat Pedhalangan Ringgit Purwa VII Episode "Pandu Papa." Jurnal Pendidikan Sejarah Indonesia, 1(1), 75-84. Diambil dari http://www.jurnalpsi.com/index.php/jpsi/article/view/6

Pigeaud, T. G. Th., \& de Graaf, H. J. (1976). The Reign of Sultan Agung of Mataram 1613-1645 and his Predecessor Panembahan Seda-Ing-Krapyak 1601-1613. Dalam T. G. Th. Pigeaud \& H. J. de Graaf (Ed.), Islamic States in Java 1500-1700: Eight Dutch Books and Articles by Dr H.J. de Graaf (hlm. 35-51). Dordrecht: Springer Netherlands. doi: 10.1007/978-94-015-71876_3 
Prihatmojo, A., \& Badawi, B. (2020). Pendidikan Karakter di Sekolah Dasar Mencegah Degradasi Moral di Era 4.0. DWIJA CENDEKIA: Jurnal Riset Pedagogik, 4(1), 142-152. doi: 10.20961/jdc.v4i1.41129

Reid, A. (1988). Female Roles in Pre-Colonial Southeast Asia. Modern Asian Studies, 22(3), 629645. Diambil dari https://www.jstor.org/stable/312601

Ricklefs, M. C. (2009). Sejarah Indonesia Modern 1200-2008. Jakarta: Serambi.

Robson, S. O. (1981). Java at the crossroads; Aspects of Javanese Cultural history in the 14th and 15th centuries. Bijdragen Tot de Taal-, Land-En Volkenkunde / Journal of the Humanities and Social Sciences of Southeast Asia, 137(2-3), 259-292. doi: 10.1163/2213437990003500

Sahronih, S. (2018). Implementasi Nilai-Nilai Pendidikan Karakter dalam Mengatasi Degradasi Moral Anak Sekolah Dasar di Era Digital. Prosiding Seminar Dan Diskusi Pendidikan Dasar. Diambil dari http://journal.unj.ac.id/unj/index.php/psdpd/article/view/10188

Sapto, A. (2017). Pelestarian Kekuasaan Pada Masa Mataram Islam: Sebha Jaminan Loyalitas Daerah Terhadap Pusat 1. Sejarah dan Budaya : Jurnal Sejarah, Budaya, dan Pengajarannya, 9(2), 153-161. Diambil dari http://journal2.um.ac.id/index.php/sejarahdan-budaya/article/view/1531

Sari, S. P., \& Bermuli, J. E. (2021). Etika Kristen dalam Pendidikan Karakter dan Moral Siswa di Era Digital. Diligentia: Journal of Theology and Christian Education, 3(1), 46-63. doi: 10.19166/dil.v3i1.2782

Saussure, F. de. (1959). Course de General Linguistic (W. Baskin, Penerj.). New York: Columbia University Press.

Simarmata, N., Yuniarti, K. W., Riyono, B., \& Patria, B. (2020). Gotong Royong in Organization. International Journal of Social Welfare Promotion and Management, 7(2), 1-8. doi: 10.21742/IJSWPM.2020.7.2.01

Utami, A. D. I., Warto, W., \& Sariyatun, S. (2018). Penguatan Pendidikan Karakter Melalui Pembelajaran Sejarah Berbasis Kitab Kuntara Raja Niti. Jurnal Pendidikan Sejarah Indonesia, 1(1), 63-74. doi: http://www.jurnalpsi.com/index.php/jpsi/article/view/2

van Zoest, A. (1990). Fiksi dan Nonfiksi dalam Kajian Semiotik (S. Manoekmi, Penerj.). Jakarta: Intermasa.

Walker, D. I., Roberts, M. P., \& Kristjánsson, K. (2015). Towards a new era of character education in theory and in practice. Educational Review, 67(1), 79-96. doi: 10.1080/00131911.2013.827631

Wardani, Y. F. (2018). Nilai Pendidikan Karakter dalam Novel Rindu Karangan Tere Liye: Tinjauan Psikologi Karakter. AKSIS: Jurnal Pendidikan Bahasa Dan Sastra Indonesia, 2(2), 246-274. doi: 10.21009/AKSIS.020207 